\title{
Severe exacerbation of psoriasis after cessation of methotrexate therapy successfully treated with cyclosporin A
}

\section{Ciężkie zaostrzenie łuszczycy po odstawieniu metotreksatu skutecznie leczone cyklosporyną A}

\author{
Aleksandra Bartczyszyn-Kmiecik', Magdalena Żychowska', Radomir Reszke', Adam Reich',2 \\ 'Department of Dermatology, Venereology and Allergology, Wroclaw Medical University, Poland \\ 2Department of Dermatology, University of Rzeszow, Poland \\ 'Katedra i Klinika Dermatologii, Wenerologii i Alergologii Uniwersytetu Medycznego we Wrocławiu, Polska \\ 2Zakład i Klinika Dermatologii, Uniwersytet Rzeszowski, Polska
}

\section{CORRESPONDING AUTHOR/ ADRES DO KORESPONDENCJI: dr hab. med. Adam Reich, prof. nadzw. \\ Zakład i Klinika Dermatologii Uniwersytet Rzeszowski ul. Szopena 2, 35-055 Rzeszów tel.: +48 605076722 e-mail: adi_medicalis@go2.pl}

\begin{abstract}
Introduction. It is estimated that erythroderma affects about $1-2 \%$ of patients with psoriasis.

Objective. To present a case of psoriatic erythroderma, which was effectively treated with cyclosporin A.

Case report. A 31-year-old man was admitted to the department to treat erythroderma. Approximately 3 weeks prior to hospital admission he discontinued methotrexate treatment which, in addition with upper respiratory tract infection resulted in rapid recurrence of psoriatic lesions and development of erythroderma. Methotrexate $20 \mathrm{mg}$ weekly was re-introduced to treat skin lesions. Despite such treatment, no satisfactory improvement was achieved. On the $13^{\text {th }}$ day of hospitalization it was decided to start cyclosporin A (initially $200 \mathrm{mg} /$ day, next increased to $300 \mathrm{mg} /$ day). Cyclosporin A treatment was effective and well tolerated.

Conclusions. Discontinuation of systemic treatment in patients with psoriasis may be associated with an exacerbation of the skin condition including erythroderma. Cyclosporin A is a valuable therapeutic option for patients with psoriatic erythroderma. The treatment is characterized by a rapid onset of action, good efficacy and generally favourable safety profile.
\end{abstract}

\section{STRESZCZENIE}

Wprowadzenie. Ocenia się, że erytrodermia dotyczy ok. 1-2\% pacjentów z łuszczycą.

Cel pracy. Przedstawienie przypadku erytrodermii łuszczycowej skutecznie leczonej cyklosporyną A.

Opis przypadku. Mężczyzna 31-letni został przyjęty w celu leczenia erytrodermii łuszczycowej. Około 3 tygodnie przed hospitalizacją u chorego zaprzestano stosowania metotreksatu. Przerwanie leczenia tym lekiem oraz dodatkowo infekcja górnych dróg oddechowych spowodowała szybki nawrót zmian łuszczycowych i rozwój erytrodermii. W tera- 
pii zdecydowano o ponownym włączeniu do leczenia metotreksatu w dawce $20 \mathrm{mg} /$ tydzień. Mimo tak stosowanej terapii nie uzyskano zadowalającej poprawy. Z tego powodu w 13. dobie hospitalizacji zdecydowano o dołączeniu cyklosporyny A (początkowo w dawce 200 $\mathrm{mg} /$ dobę, następnie dawkę zwiększono do $300 \mathrm{mg} /$ dobę), uzyskując szybką poprawę kliniczną. Leczenie cyklosporyną A było dobrze tolerowane.

Wnioski. Odstawienie leczenia ogólnego u pacjentów z łuszczycą może się wiązać z pogorszeniem stanu skóry, a nawet z erytrodermią. Cyklosporyna A jest wartościową opcją terapeutyczną u chorych z erytrodermią łuszczycową, cechującą się szybkim początkiem działania, dobrą skutecznością i zazwyczaj korzystnym profilem bezpieczeństwa.

Key words: erythroderma, treatment, psoriasis.

Słowa kluczowe: erytrodermia, leczenie, łuszczyca.

\section{INTRODUCTION}

Erythroderma refers to generalized dermatitis which involves $90 \%$ or more of the patient's skin [1]. In addition to erythema, the disease is associated with oedema, exudate and increased epidermal exfoliation. Erythroderma is also usually accompanied by systemic symptoms such as elevated body temperature, general malaise and intense pruritus. The causes of erythroderma are thought to include psoriasis, atopic dermatitis, occasionally drug-induced skin lesions, pityriasis rubra pilaris or erythrodermic stages of primary cutaneous T-cell lymphomas [1].

Erythroderma is estimated to affect about $1-2 \%$ of patients with psoriasis [2]. The risk of erythroderma secondary to psoriasis is increased by periodic treatments with systemic glucocorticosteroids, aggressive topical therapy of psoriatic lesions, inadequate phototherapy regimen or rapid discontinuation of prior systemic psoriasis treatment. Psoriatic erythroderma is a potentially life-threatening condition. Consequently, patients require strict medical supervision until the symptoms of the disease are controlled. Therapy should be adjusted to the severity of skin lesions and accompanying systemic symptoms, and to the acute or chronic nature of erythroderma. However, since psoriatic erythroderma occurs infrequently, the literature does not include high quality studies comparing the efficacy of different therapeutic modalities employed in the treatment of this variant of psoriasis [2,3]. As a result, recommended therapeutic options are largely based on isolated case reports describing effective treatment of psoriatic erythroderma and the clinical experience of researchers developing a particular set of therapeutic recommendations. Available treatment options include drugs with rec-

\section{WPROWADZENIE}

Mianem erytrodermii określa się uogólniony stan zapalny skóry, który obejmuje co najmniej 90\% jej powierzchni [1]. Zaczerwienieniu skóry towarzyszy obrzęk, wysięk i wzmożone złuszczanie naskórka. Zwykle obserwuje się także objawy ogólne w postaci podwyższenia temperatury ciała, ogólnego złego samopoczucia oraz nasilonego świądu. Wśród przyczyn erytrodermii wymienia się m.in.: łuszczycę, atopowe zapalenie skóry, niekiedy osutki polekowe, łupież czerwony mieszkowy czy erytrodermiczne stadia pierwotnych chłoniaków skóry T-komórkowych [1].

Ocenia się, że erytrodermia dotyczy ok. 1-2\% pacjentów z łuszczycą [2]. Ryzyko wystąpienia erytrodermii w przebiegu łuszczycy zwiększają okresowe stosowanie ogólnych glikokortykosteroidów, agresywna terapia miejscowa zmian łuszczycowych, nieodpowiednio prowadzona fototerapia lub gwałtowne odstawienie dotychczasowego leczenia ogólnego łuszczycy. Erytrodermia łuszczycowa stanowi potencjalny stan zagrożenia życia, dlatego chorzy powinni pozostawać pod ścisłym nadzorem lekarskim do czasu opanowania objawów. Leczenie należy dostosować do stopnia nasilenia zmian skórnych i towarzyszących objawów ogólnych oraz ostrego lub przewlekłego charakteru erytrodermii. Ze względu na stosunkowo rzadkie występowanie erytrodermii łuszczycowej w piśmiennictwie nie ma dobrych jakościowo badań porównujących skuteczność poszczególnych metod terapeutycznych w tej postaci łuszczycy [2,3]. Z tego powodu ewentualne zalecenia terapeutyczne opierają się głównie na pojedynczych opisach przypadków skutecznego leczenia erytrodermii łuszczycowej oraz na doświadczeniu klinicznym 
ognized therapeutic efficacy including methotrexate, cyclosporin A, retinoids and biologic drugs [2-5]. The case report presents a patient with plaque psoriasis who developed erythroderma shortly after the discontinuation of oral methotrexate therapy. The condition was effectively treated with cyclosporin A.

\section{OBJECTIVE}

The aim of the study was to present a case of psoriatic erythroderma, which was effectively treated with cyclosporin A.

\section{CASE REPORT}

A 31-year-old man with no remarkable history of systemic diseases, but with a positive family history of psoriasis, was admitted to the Department of Dermatology, Venereology and Allergology in Wroclaw for diagnostics and treatment of a severe exacerbation of psoriatic skin lesions. The diagnosis of plaque psoriasis was established about 15 years before, at the age of 16 years. In the past, because of a severe course of the disease, the patient was treated for psoriasis with cyclosporin A (about 15 years earlier for 3 years), with the biologic drug ustekinumab (for 3 years), and with acitretin and methotrexate (for about 4 years). Methotrexate therapy at $10 \mathrm{mg}$ / week subcutaneously was re-introduced during a hospital stay which took place about half a year before the current hospitalization and was continued on an outpatient basis at $15 \mathrm{mg} /$ week. As the patient reported, treatment with methotrexate led to an almost complete remission of psoriatic lesions, and the improvement was sustained throughout the entire period of methotrexate therapy. However, methotrexate was discontinued about 3 weeks prior to the current hospitalization. Furthermore, approximately 2 weeks prior to the current hospital admission the patient was diagnosed with upper respiratory tract infection which was treated with oral antibiotics (initially amoxicillin, followed by amoxicillin combined with clavulanic acid until the hospitalization). The discontinuation of methotrexate, likely in conjunction with the ongoing upper respiratory tract infection, led to the development of erythroderma about 7 days before the current hospitalization.

On the day of admission to the Department, the patient was in a good general condition, with stable circulatory and respiratory function, in logical verbal contact, with no fever and no signs of autopsychic and allopsychic disorientation. The skin was affected by erythroderma with extensive epidermal desquamation (Fig. 1). Coalescing psoriatic plaques covered with thick scales were observed on the scalp. Severe ich autorów. Wśród dostępnych opcji terapeutycznych wymienia się leki, których skuteczność jest ogólnie uznana, tj. metotreksat, cyklosporynę $\mathrm{A}$, retinoidy oraz leki biologiczne [2-5]. W niniejszej pracy przedstawiamy przypadek pacjenta chorującego na łuszczycę plackowatą, u którego po odstawieniu doustnej terapii metotreksatem doszło do szybkiego rozwoju erytrodermii, skutecznie leczonej cykosporyną A.

\section{CEL PRACY}

Celem pracy było przedstawienie przypadku erytrodermii łuszczycowej skutecznie leczonej cyklosporyną A.

\section{OPIS PRZYPADKU}

Mężczyzna 31-letni, bez istotnych obciążeń chorobami ogólnoustrojowymi, z rodzinnym wywiadem łuszczycy został przyjęty do Kliniki Dermatologii, Wenerologii i Alergologii we Wrocławiu w celu diagnostyki i leczenia ciężkiego zaostrzenia zmian skórnych w przebiegu łuszczycy. Rozpoznanie łuszczycy plackowatej ustalono ok. 15 lat wcześniej, w wieku 16 lat. W przeszłości ze względu na ciężki przebieg schorzenia $\mathrm{w}$ terapii łuszczycy u pacjenta stosowano cyklosporynę A (ok. 15 lat wcześniej, przez 3 lata), leczenie biologiczne ustekinumabem (przez 3 lata), a także acytretynę i metotreksat (przez ok. 4 lata). Terapia metotreksatem w dawce $10 \mathrm{mg} /$ tydzień podskórnie została rozpoczęta powtórnie $\mathrm{w}$ trakcie pobytu szpitalnego około pół roku przed obecną hospitalizacją i była kontynuowana w trybie ambulatoryjnym w dawce $15 \mathrm{mg} /$ tydzień. Na podstawie relacji pacjenta ustalono, że zastosowanie metotreksatu spowodowało niemal całkowite ustąpienie zmian łuszczycowych, a poprawa utrzymywała się przez cały okres stosowania leku. Leczenie metotreksatem przerwano jednak ok. 3 tygodni przed obecną hospitalizacją. Ponadto ok. 2 tygodni przed przyjęciem do szpitala u pacjenta rozpoznano zakażenie górnych dróg oddechowych, w którego leczeniu stosowano antybiotykoterapię doustną (początkowo amoksycylinę, a następnie amoksycylinę z kwasem klawulanowym do czasu hospitalizacji). Zaprzestanie stosowania metotreksatu oraz najprawdopodobniej tocząca się infekcja górnych dróg oddechowych spowodowały rozwój erytrodermii około 7 dni przed obecną hospitalizacją.

W dniu przyjęcia do Kliniki pacjent był w stanie ogólnym dobrym, wydolny krążeniowo i oddechowo, w logicznym kontakcie słownym, bez gorączki, prawidłowo zorientowany auto- $\mathrm{i}$ alopsychicznie. Na skórze obserwowano erytrodermię z rozległym spełzaniem naskórka (ryc. 1). Na skórze owłosionej 
lesions were also noted on the nails of the hands and feet. The lesions were accompanied by intense pruritus. Furthermore, clinical manifestations of acute pharyngitis and tonsilitis were identified, together with infection foci in the oral cavity including tooth decay as well as dental, supra- and subgingival deposits of calculus over dental crowns, and signs of inflammation involving the marginal periodontium. Laboratory tests revealed leukocytosis with neutrophilia - leukocyte count $11,890 / \mu 1$ (normal range: $4,000-10,000 / \mu \mathrm{l}$ ), neutrophil count $9,710 / \mu \mathrm{l}$ (normal głowy występowały zlewne blaszki łuszczycowe pokryte grubą łuską. Obecne były również nasilone zmiany paznokci rąk i stóp. Zmianom towarzyszył silny świąd. Ponadto klinicznie stwierdzono cechy ostrego zapalenia błony śluzowej gardła i migdałków podniebiennych, a także obecność ognisk infekcyjnych w jamie ustnej, m.in. ubytki próchnicowe zębów, liczne złogi nazębne nad- i poddziąsłowe pokrywające korony zębów oraz cechy stanu zapalnego przyzębia brzeżnego. W badaniach laboratoryjnych stwierdzono leukocytozę z neutrofilią - leukocyty
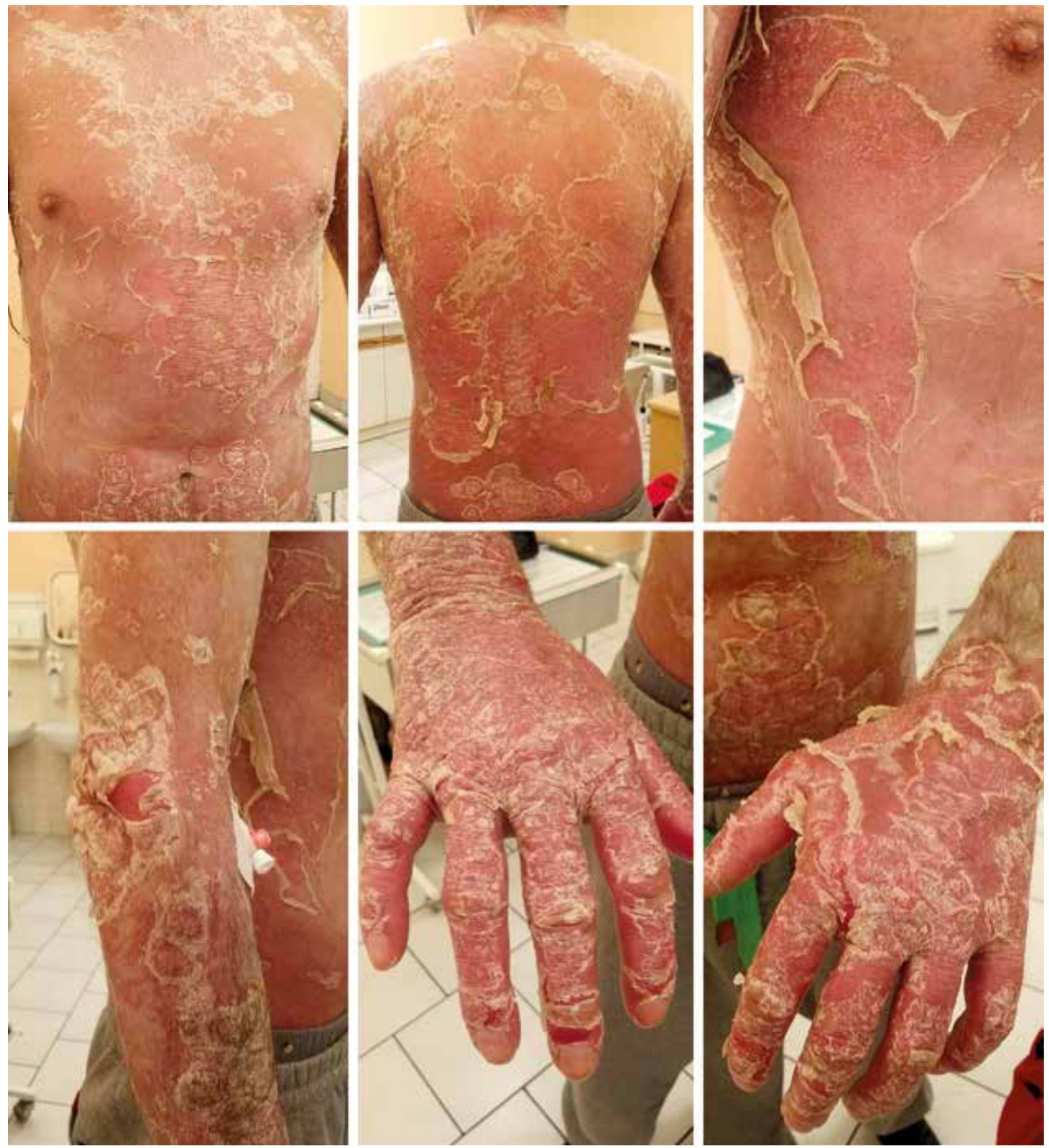

Figure I. Patient's clinical condition on admission to the Department

Rycina I. Stan kliniczny pacjenta w chwili przyjęcia do Kliniki 
range: $1,600-7,000 / \mu 1)$, increased levels of inflammatory markers - ESR $57 \mathrm{~mm} / \mathrm{h}$ (normal range: 3-8 mm/h), C-reactive protein (CRP) $138.5 \mathrm{mg} / 1$ (normal range: $0.2-5 \mathrm{mg} / 1$ ), procalcitonin $0.15 \mathrm{ng} / \mathrm{ml}$ (normal range $<0.05 \mathrm{ng} / \mathrm{ml}$ ) and high antistreptolysin titre (ASO) 8,580 IU/ml (normal range: 0-200 IU/ $\mathrm{ml}$ ). During the period of hospitalization, in view of very severe skin lesions, short-term systemic treatment with hydrocortisone $2 \times 100 \mathrm{mg}$ i.v. was introduced with gradual dose reduction until complete withdrawal after 7 days of therapy. In addition, combined therapy with amoxicillin and clavulanic acid, which was initiated prior to the admission to the Department, was continued until day 11 of hospitalization. Topical medications were also used throughout the entire hospitalization period. On day 3 of hospitalization, a decision was made to reintroduce subcutaneously administered methotrexate at a weekly dose of $20 \mathrm{mg}$. On the following day of treatment fever of up to $38.5^{\circ} \mathrm{C}$ was observed and laboratory tests showed a progressive increase in inflammatory markers and features of impaired liver function (leukocyte count $12,320 / \mu 1$, neutrophil count $9,050 / \mu 1$, CRP $89.4 \mathrm{mg} / 1$, procalcitonin $0.31 \mathrm{ng} / \mathrm{ml}$, serum asparagine aminotransferase activity $168 \mathrm{U} / 1$ (normal range: 5-34 U/1), serum alanine aminotransferase activity: $176 \mathrm{U} / 1$ (normal range: $0-55 \mathrm{U} / 1)$, $\gamma$-glutamyl transpeptidase activity: $177 \mathrm{U} / 1$ (normal range: 12-64 U/1), prothrombin time $15.5 \mathrm{~s}$ (normal range: 10-12 s), ASO 9,470 IU/ml). Extended diagnostic assessment included imaging studies (echocardiography: no abnormalities, abdominal ultrasound: the only abnormalities were features of hepatic steatosis), microbiological tests (blood and urine cultures: negative; nasopharyngeal swab test: no pathogenic flora was detected). On account of severe skin lesions, methotrexate therapy was maintained, and antibiotic therapy was modified by introducing imipenem with cilastatin which was continued for 8 days. The observed increase in liver markers was attributed to the combined effect of high-burden systemic antibiotic therapy and methotrexate, and was thought to be likely transient. The thesis was corroborated in follow-up laboratory tests which were repeatedly performed, demonstrating gradual normalization of liver damage markers. However, the patient's skin condition failed to improve significantly in response to methotrexate monotherapy. Since the therapeutic effect was not satisfactory, on day 13 of hospitalization cyclosporin A was added to the regimen (at a dose of $200 \mathrm{mg} /$ day, i.e. $2.6 \mathrm{mg} /$ $\mathrm{kg}$ b.w., subsequently increased to $300 \mathrm{mg} /$ day, i.e. $3.8 \mathrm{mg} / \mathrm{kg}$ b.w.), achieving a marked improvement in skin condition within approximately 2 weeks (Fig. 2). Since methotrexate combined with cyclosporin A carries an increased risk of immunosuppression and
11 890/ $\mu \mathrm{l}$ (norma: 4000-10 000/ $\mu \mathrm{l}$ ), neutrofile $9710 / \mu \mathrm{l}$ (norma: 1600-7000/ $\mu$ l), podwyższenie poziomu wykładników stanu zapalnego - OB $57 \mathrm{~mm} /$ godz. (norma: 3-8 mm/godz.), stężenie białka C-reaktywnego (CRP) $138,5 \mathrm{mg} / 1$ (norma: 0,2-5 mg/1), prokalcytoniny $0,15 \mathrm{ng} / \mathrm{ml}$ (norma $<0,05 \mathrm{ng} / \mathrm{ml}$ ) oraz wysokie miano antystreptolizyny (ASO) $8580 \mathrm{IU} / \mathrm{ml}$ (norma: 0-200 $\mathrm{IU} / \mathrm{ml}$ ). W trakcie hospitalizacji ze względu na bardzo duże nasilenie zmian skórnych w terapii krótkotrwale zastosowano hydrokortyzon $2 \times 100 \mathrm{mg}$ i.v. ze stopniową redukcją dawki aż do pełnego odstawienia po 7 dniach. Kontynuowano również rozpoczętą przed przyjęciem do Kliniki doustną antybiotykoterapię amoksycyliną z kwasem klawulanowym (do 11. doby leczenia). Przez cały okres hospitalizacji stosowano również preparaty miejscowe. W 3. dobie hospitalizacji zdecydowano o ponownym włączeniu do terapii metotreksatu podawanego podskórnie w dawce $20 \mathrm{mg} /$ tydzień. W kolejnym dniu leczenia nastąpił wzrost temperatury ciała do $38,5^{\circ} \mathrm{C}$, a w badaniach laboratoryjnych stwierdzono narastanie parametrów stanu zapalnego oraz cechy uszkodzenia wątroby (leukocyty $12320 / \mu 1$, neutrofile 9050/ $\mu$ l, CRP $89,4 \mathrm{mg} / 1$, prokalcytonina $0,31 \mathrm{ng} / \mathrm{ml}$, aktywność aminotransferazy asparaginianowej w surowicy 168 U/1 (norma: 5-34 U/1), aktywność aminotransferazy alaninowej w surowicy $176 \mathrm{U} / 1$ (norma: 0-55 U/1), aktywność $\gamma$-glutamylotranspeptydazy 177 U/1 (norma: 12-64 U/1), czas protrombinowy 15,5 s (norma: 10-12 s), ASO 9470 IU/ml). Diagnostykę rozszerzono o liczne badania dodatkowe - obrazowe (badanie echokardiograficzne - nie stwierdzono nieprawidłowości, USG jamy brzusznej - stwierdzono jedynie cechy stłuszczenia wątroby) i mikrobiologiczne (posiewy krwi i moczu - jałowe, wymaz z jamy nosowej i gardła - nie wyhodowano flory patogennej). Ze względu na utrzymujące się duże nasilenie zmian skórnych kontynuowano terapię metotreksatem, a także zmodyfikowano antybiotykoterapię, podając imipenem z cylastatyną przez 8 dób. Uznano, że podwyższenie parametrów wątrobowych jest wynikiem koincydencji obciążającej antybiotykoterapii ogólnej oraz przyjmowania metotreksatu i prawdopodobnie ma charakter przejściowy. Tezę tę potwierdzono w kontrolnych badaniach laboratoryjnych, które wykonywano wielokrotnie i w których wykazano stopniową normalizacje parametrów uszkodzenia wątroby. W trakcie monoterapii metotreksatem stan skóry pacjenta nie poprawił się jednak znacząco. W związku z niezadowalającym efektem terapeutycznym w 13. dobie hospitalizacji zdecydowano o dołączeniu cyklosporyny A (w dawce $200 \mathrm{mg} /$ dobę - tj. 2,6 mg/kg m.c., którą następnie zwiększono do $300 \mathrm{mg} /$ dobę - tj. 3,8 mg/kg m.c.). Uzyskano istotną poprawę stanu skóry w ciągu niespełna 2 tygodni (ryc. 2). Ze względu na wzrost ryzyka immunosupre- 
hepatotoxicity, on day 24 of hospitalization a decision was made to discontinue methotrexate (after 4 doses), and treatment was continued with cyclosporin $\mathrm{A}$ in monotherapy at a dose of $300 \mathrm{mg} /$ day. The level of cyclosporin A assayed in the blood was within the therapeutically desired range. The patient's follow-up to date revealed no adverse reactions or toxicity associated with cyclosporin A treatment. The parameters of kidney and liver function were within the normal range, and no increase in blood pressure was noted during measurements. The patient was discharged home on day 32 of hospitalization, in a good general state and with significant improvement in skin condition (Fig. 3), with the recommendation to continue cyclosporin A treatment under the control of a dermatologist.

\section{DISCUSSION}

The treatment of psoriatic erythroderma presents a great therapeutic challenge. It must take into ac- sji i hepatotoksyczności metotreksatu w terapii skojarzonej z cyklosporyną A w 24 . dobie podjęto decyzję o odstawieniu metotreksatu (po 4 dawkach), a w dalszym leczeniu zastosowano monoterapię cyklosporyną A w dawce $300 \mathrm{mg} /$ dobę. Stężenie cyklosporyny A we krwi utrzymywało się w granicach pożądanych wartości terapeutycznych. W trakcie obserwacji pacjenta nie stwierdzono żadnych działań niepożądanych i toksyczności cyklosporyny A - parametry czynności nerek i wątroby były prawidłowe, nie odnotowano zwyżek ciśnienia tętniczego. Pacjenta wypisano do domu w 32. dobie hospitalizacji w stanie ogólnym dobrym i ze znaczną poprawą stanu miejscowego (ryc. 3), z zaleceniem kontynuowania leczenia cyklosporyną A pod nadzorem dermatologa.

\section{OMÓWIENIE}

Leczenie erytrodermii łuszczycowej stanowi duże wyzwanie. Musi ono uwzględniać nie tylko potrze-
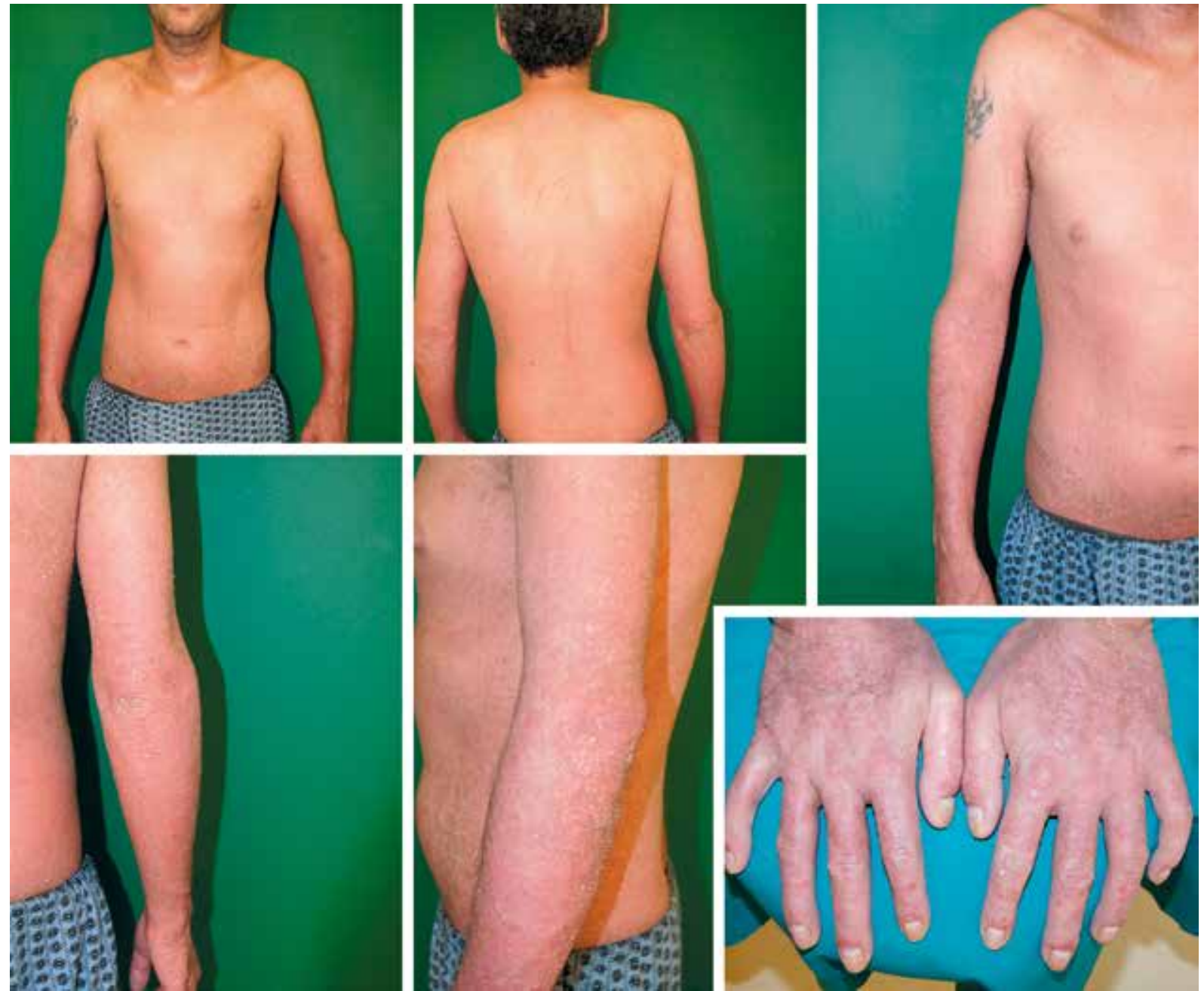

Figure 2. Patient's condition a week after the initiation of treatment with cyclosporin A

Rycina 2. Stan pacjenta po tygodniu od rozpoczęcia leczenia cyklosporyna A 
count not only the need for rapid disease control but also coexisting general medical disorders and risks associated with the treatment itself. As previously mentioned, the literature does not describe any established therapeutic regimens applicable to psoriatic erythroderma. The proposed therapeutic modality should be adjusted to the patient's current clinical condition, taking into account the severity of systemic symptoms and skin manifestations [2].

One of the causes of erythroderma in the presented patient was the discontinuation of methotrexate used in the treatment of psoriasis. Another likely cause that contributed to the development and persistence of psoriatic lesions in the case discussed bę uzyskania szybkiej kontroli choroby, lecz także współistniejące schorzenia internistyczne oraz bezpieczeństwo samej terapii. Jak wspomniano, w piśmiennictwie nie ma jednoznacznych schematów leczenia tej postaci łuszczycy. Proponowana terapia powinna być dostosowana do aktualnego stanu klinicznego pacjenta, z uwzględnieniem ciężkości objawów ogólnych oraz zmian skórnych [2].

U przedstawionego pacjenta jedną z przyczyn powstania erytrodermii było odstawienie metotreksatu stosowanego w terapii łuszczycy. Na wyzwolenie i podtrzymywanie zmian łuszczycowych w opisywanym przypadku prawdopodobnie miała też wpływ infekcja górnych dróg oddechowych, która nałożyła
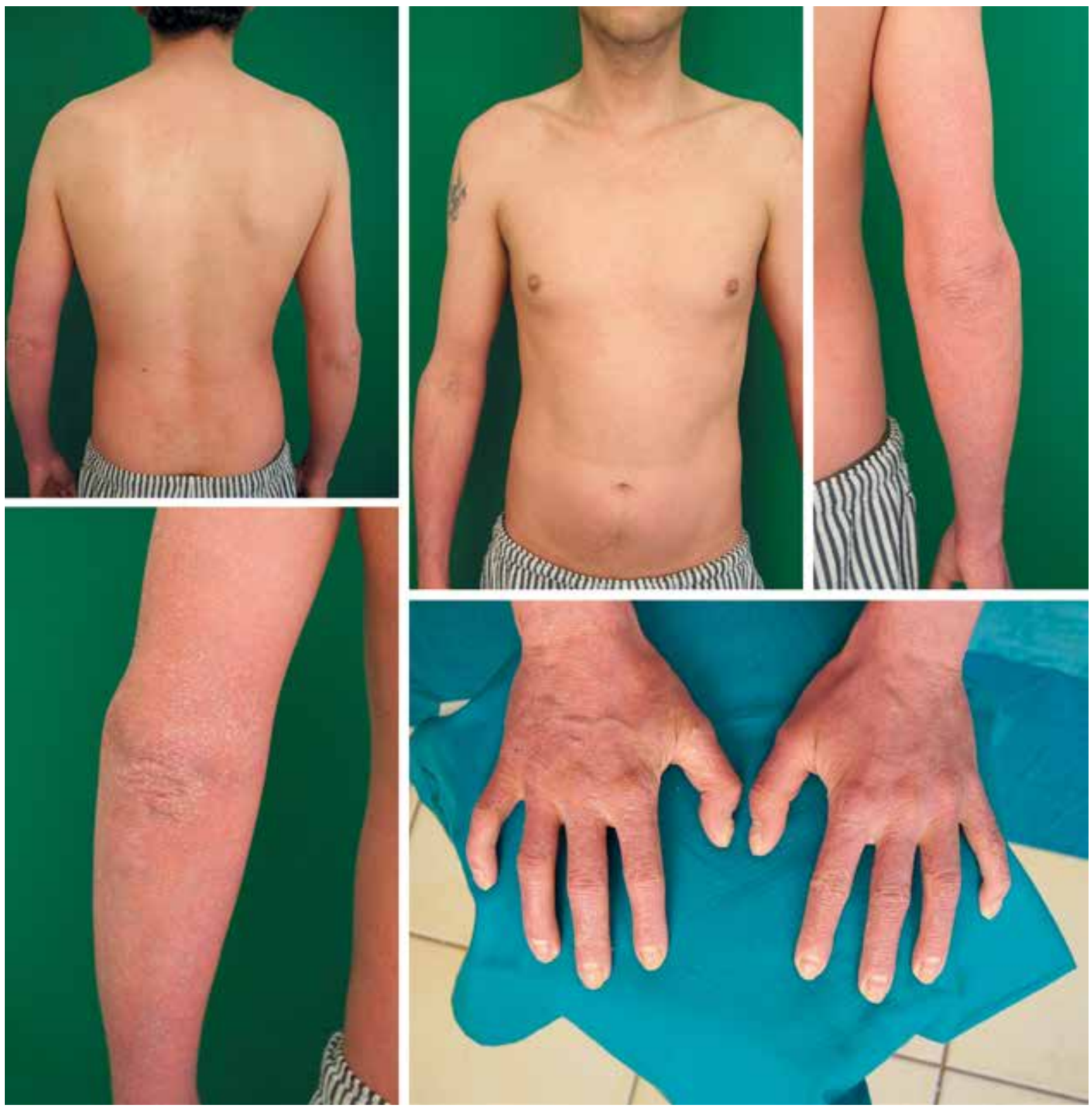

Figure 3. Patient's condition on the day of discharge from the hospital 18 days after the initiation of treatment with cyclosporin A

Rycina 3. Stan pacjenta w dniu mpisu ze szpitala, po 18 dniach od rozpoczęcia leczenia cyklosporyna A 
was upper respiratory tract infection which coincided with the exacerbation of the disease. Since the patient previously responded well to methotrexate therapy, on his admission to the hospital a decision was made to re-introduce the drug. However, since the therapeutic effect was unsatisfactory, cyclosporin A was added to the treatment regimen within a short time, leading to a rapid clinical improvement. The available literature describes cases of effective combination therapy with methotrexate and cyclosporin A in cases of severe treatment-refractory psoriasis including erythrodermic psoriasis [6-10]. It represents a potential alternative therapy in patients who do not tolerate well high doses of a single drug or whose condition fails to improve sufficiently in response to treatment based on one of the two medications. Combined treatment may lead to more rapid regression of cutaneous lesions, however it should be stressed that such therapy carries a greater risk of adverse reactions, particularly infectious complications [11]. On the other hand, based on the available data [6-10], methotrexate combined with cyclosporin A seems to be a relatively safe therapeutic modality, provided that follow-up examinations are systematically performed and the treatment is monitored on an ongoing basis. It is important to note, though, that data on the long-term safety of using this drug combination are insufficient. Considering that methotrexate combined with cyclosporin A increases the risk of immunosuppression and hepatotoxicity, the goal should be to reduce the period of concurrent use of both drugs.

The literature contains recommendations regarding cyclosporin A as a first-line drug in patients with severe psoriatic erythroderma [2]. In the case discussed, methotrexate was the initial therapeutic option, as it was previously effective in the patient, however this time significant improvement was not achieved. The discontinuation of methotrexate had no adverse impact on the course of treatment. Thanks to continuing of cyclosporin A treatment further clinical improvement was observed.

Cyclosporin A remains one of the main systemic drugs used in the therapy of severe forms of psoriasis. It demonstrates high efficacy in cases where rapid therapeutic improvement is a priority, since out of three available systemic drugs used in the treatment of psoriasis (cyclosporin A, methotrexate and acitretin), cyclosporin $\mathrm{A}$ is characterized by the earliest onset of action [3]. Moreover, unlike other systemic drugs used in psoriasis therapy, cyclosporin A has not been reported to adversely affect patients' fertility. As a consequence, cyclosporin A should be used primarily in young patients who have not completed their procreation plans yet. się czasowo na zaostrzenie choroby. Ponieważ wcześniej u chorego obserwowano dobrą odpowiedź na leczenie metotreksatem, po jego zgłoszeniu się do szpitala zdecydowano o ponownym włączeniu tego leku. Jednak ze względu na niezadowalający efekt terapeutyczny w krótkim czasie dołączono do leczenia cyklosporynę A i uzyskano szybką poprawę kliniczną. W dostępnym piśmiennictwie opisywano przypadki skutecznej terapii z zastosowaniem połączenia metotreksatu z cyklosporyną A ciężkiej, opornej na leczenie łuszczycy, w tym łuszczycy erytrodermicznej [6-10]. Stanowi ono potencjalną terapię alternatywną u tych chorych, którzy źle tolerują duże dawki pojedynczego leku lub nie osiągają wystarczającej poprawy przy stosowaniu tylko jednego z nich. Leczenie skojarzone może powodować szybsze ustępowanie zmian skórnych, ale jednocześnie należy pamiętać, że w trakcie takiej terapii wzrasta ryzyko wystąpienia ewentualnych działań niepożądanych, zwłaszcza powikłań infekcyjnych [11]. Na podstawie dostępnych danych [6-10] wydaje się jednak, że terapia skojarzona metotreksatem i cyklosporyną A jest stosunkowo bezpieczna, pod warunkiem odpowiedniego nadzoru oraz systematycznego wykonywania i monitorowania badań kontrolnych. Należy również podkreślić, że brakuje wystarczających danych dotyczących długotrwałego bezpieczeństwa stosowania takiego połaczenia. Ze względu na wzrost ryzyka immunosupresji i hepatotoksyczności metotreksatu w terapii skojarzonej z cyklosporyną A należy dążyć do ograniczenia czasu stosowania jednocześnie tych leków.

W piśmiennictwie można znaleźć rekomendacje dotyczące zastosowania cyklosporyny A jako leku pierwszego wyboru w ciężkiej postaci erytrodermii łuszczycowej [2]. W przedstawionym przypadku leczenie rozpoczęto jednak od metotreksatu, ponieważ wcześniej ten lek był u pacjenta skuteczny, ale tym razem nie uzyskano zadowalającej poprawy. Ponadto odstawienie metotreksatu nie pogorszyło przebiegu łuszczycy, ale dzięki kontynuowaniu leczenia cyklosporyną A obserwowano dalszą poprawę kliniczną.

Cyklosporyna A jest jednym z podstawowych leków ogólnych stosowanych w terapii ciężkich postaci łuszczycy. Lek ten dobrze sprawdza się w sytuacji, gdy konieczne jest uzyskanie szybkiego efektu terapeutycznego. Spośród trzech głównych leków ogólnych stosowanych w terapii łuszczycy (cyklosporyna A, metotreksat i acytretyna) cyklosporyna A cechuje się najwcześniejszym początkiem działania [3]. Ponadto nie ma danych o negatywnym wpływie tego leku na płodność pacjentów, w przeciwieństwie do innych leków ogólnych stosowanych w łuszczycy. Dobrymi kandydatami do leczenia łuszczycy cyklosporyną A są przede wszystkim osoby młode, które mają jeszcze plany prokreacyjne. 


\section{CONCLUSIONS}

It needs to be emphasized that the discontinuation of systematic treatment controlling the disease in patients with psoriasis may be associated with an exacerbation of the skin condition including erythroderma. Effective control of erythroderma secondary to psoriasis still poses a great therapeutic challenge. The difficulty lies both in the selection of therapy appropriate in a particular case and in the evaluation of potential risk of toxicity and adverse reactions associated with systemic treatment, particularly in combination treatment. Further research in the field is necessary to support the development of safer and more effective treatment regimens including combined therapy.

\section{CONFLICT OF INTEREST}

The paper was prepared based on the cooperation with TEVA Poland.

\section{WNIOSKI}

Należy podkreślić, że odstawienie leczenia ogólnego kontrolującego proces chorobowy u pacjentów z łuszczycą może się wiązać z pogorszeniem stanu skóry, $\mathrm{w}$ tym $\mathrm{z}$ erytrodermią. Skuteczne opanowanie erytrodermii $\mathrm{w}$ przebiegu łuszczycy nadal stanowi duże wyzwanie terapeutyczne, przy czym trudność dotyczy zarówno wyboru skutecznej w danym przypadku terapii, jak i oceny potencjalnego ryzyka toksyczności i działań niepożądanych leków ogólnych, zwłaszcza w leczeniu skojarzonym. Konieczne są dalsze badania w tym zakresie, które pozwolą na opracowanie bezpieczniejszych i skuteczniejszych schematów leczenia, w tym terapii skojarzonej.

\section{KONFLIKT INTERESÓW}

Praca powstała $\mathrm{w}$ ramach współpracy z firmą Teva Polska.

\section{References Piśmiennictwo}

1. Mistry N., Gupta A., Alavi A., Sibbald R.G.: A review of the diagnosis and management of erythroderma (generalized red skin). Adv Skin Wound Care 2015, 28, 228-236.

2. Rosenbach M., Hsu S., Korman N.J., Lebwohl M.G., Young M., Bebo B.F. Jr, et al.: Treatment of erythrodermic psoriasis: from the medical board of the National Psoriasis Foundation. J Am Acad Dermatol 2010, 62, 655-662.

3. Szepietowski J., Adamski Z., Chodorowska G., Kaszuba A., Placek W., Rudnicka L., et al.: Leczenie łuszczycy - rekomendacje ekspertów Polskiego Towarzystwa Dermatologicznego. Część II: łuszczyca umiarkowana do ciężkiej. Przegl Dermatol 2014, 101, 455-472.

4. Warren R.B., Griffiths C.E.: Systemic therapies for psoriasis: methotrexate, retinoids, and cyclosporine. Clin Dermatol 2008, $26,438-447$.

5. Management of erythrodermic psoriasis with low-dose cyclosporin. Studio Italiano Multicentrico nella Psoriasi (SIMPSO). Dermatology 1993, 187 Suppl 1, 30-37.

6. Clark C.M., Kirby B., Morris A.D., Davison S., Zaki I., Emerson R., et al.: Combination treatment with methotrexate and cyclosporin for severe recalcitrant psoriasis. Br J Dermatol 1999, 141, 279-282.

7. Wong K.C., Georgouras K.: Low dose cyclosporin A and methotrexate in the treatment of psoriasis. Acta Derm Venereol $1999,79,87$.

8. Aydin F., Canturk T., Senturk N., Turanli A.Y.: Methotrexate and ciclosporin combination for the treatment of severe psoriasis. Clin Exp Dermatol 2006, 31, 520-524.

9. Jensen P., Skov L., Zachariae C.: Systemic combination treatment for psoriasis: a review. Acta Derm Venereol 2010, 90, 341349.

10. Mohanan S., Ramassamy S., Chandrashekar L., Thappa D.M.: A retrospective analysis of combination methotrexate-cyclosporine therapy in moderate-severe psoriasis. J Dermatolog Treat 2014, 25, 50-53.

11. Korstanje M.J., van Breda Vriesman C.J., van de Staak W.J.: Cyclosporine and methotrexate: a dangerous combination. J Am Acad Dermatol 1990, 23, 320-321.

Received: 22.07.2017

Accepted: 5.08.2017

Otrzymano: 22.07.2017 r.

Zaakceptowano: $5.08 .2017 \mathrm{r}$.

\section{How to cite this article}

Bartczyszyn-Kmiecik A., Żychowska M., Reszke R., Reich A.: Severe exacerbation of psoriasis after cessation of methotrexate therapy successfully treated with cyclosporin A. Dermatol Rev/Przegl Dermatol 2017, 107, 423-431.

DOI: https://doi.org/10.5114/dr.2017.69949. 